\title{
Preference for feeding at habitat edges declines among juvenile blue crabs as oyster reef patchiness increases and predation risk grows
}

\author{
Peter I. Macreadie ${ }^{1,2, *}$, Nathan R. Geraldi ${ }^{1}$, Charles H. Peterson ${ }^{1}$ \\ ${ }^{1}$ Institute of Marine Science, University of North Carolina, Morehead City, 28557 North Carolina, USA \\ ${ }^{2}$ Centre for Environmental Sustainability, School of the Environment, University of Technology, Sydney, \\ 2007 New South Wales, Australia
}

\begin{abstract}
Both habitat patchiness and behaviorally-mediated indirect effects (BMIEs; predator-induced changes in prey behavior that affect the prey's resources) are important in many food webs, but the relationships between these 2 factors have yet to be investigated. To explore effects of habitat patchiness and variation in perceived risk of predation on food-web dynamics, we conducted a factorial experiment in a model aquatic food chain of predator-prey-resource using 2 contrasting predators (adult blue crab Callinectes sapidus and toad fish Opsanus tau), juvenile blue crab as prey, and mussel Geukensia demissa as resource. Both predator presence and habitat patchiness influenced the prey's preference for consuming resources at patch edges instead of interiors. The preference of prey for consuming resources at habitat edges was 4 times stronger in continuous oyster reef habitat than in smaller habitat patches. This suggests that interior resources in continuous habitat experience a refuge from consumption, but this refuge is largely lost in patchy habitat. The mere presence of predators reduced the prey's preference for consuming resources at habitat edges. This BMIE was significant for the ambush predator (toadfish) and the treatment containing both predators, but not for the actively hunting predator (adult blue crab). We conclude that habitat patchiness and predator presence can jointly affect resource distribution by inducing shifts in prey foraging behavior, revealing a need to incorporate BMIEs into habitat fragmentation studies. This conclusion has broad and growing relevance as anthropogenic factors increasingly modify predator abundances and fragment coastal habitats.
\end{abstract}

KEY WORDS: Habitat fragmentation - Edge effect - Hunting mode - Non-consumptive effect · Trait-mediated indirect effect $\cdot$ Oyster reef $\cdot$ Non-lethal effect $\cdot$ Trophic cascade

\section{INTRODUCTION}

Early studies on the indirect effects of predators on food webs focused on how predators influence the abundance of resources through consumption and thus on numeric reduction of prey (e.g. Garrity \& Levings 1981, Huang \& Sih 1991). Strong trophic cascades have now been documented in diverse ecosystems (e.g. Carpenter et al. 1987, Estes \& Duggins 1995, Myers et al. 2007). Such traditional cascades are based on the effects of apex predators and represent what are termed density-mediated indirect effects (DMIEs) (Werner \& Peacor 2003). Recently, increased attention has been given to behaviorally-mediated indirect effects (BMIEs; predator-induced changes in prey behavior that indirectly affect the prey's resources - also known as trait-mediated indirect effects, TMIE), which are proving to be widespread and quantitatively meaningful (Schmitz et al. 1997, Werner \& Peacor 2003, Grabowski 2004, Trussell et al. 2006). 
For example, Preisser et al. (2005) reviewed the ecological literature and found that BMIEs are at least as important as DMIEs, which theory shows can have significant implications for resource persistence (Abrams 2008). Anti-predator behaviors by prey and their cascading consequences can have a major role in structuring many ecosystems (Heithaus et al. 2008).

Patchiness and anthropogenically induced fragmentation of habitat have likewise been shown to influence predator- prey interactions (Kareiva 1987, Morris \& Davidson 2000, Wolf \& Batzli 2004, Orrock $\&$ Danielson 2005). As patch size declines, the habitat patch may no longer provide sufficient prey abundance to support predators (e.g. Macreadie et al. 2010b). The loss of apex predators can release their prey from predatory control, which in turn can result in those prey over-exploiting their own food resources (Crooks \& Soule 1999, Myers et al. 2007). Although many examples exist of how perceived risks of predation alter prey use of structured habitat (Hall et al. 1970, Ewers \& Didham 2006, Heithaus et al. 2007), much less attention has been given to how changes in habitat patchiness might influence BMIEs. Because the capacity of structured habitat to provide refuge from predation may be expected to decline as habitat patches become smaller, research is needed to assess how habitat patchiness and predation risk interact to influence prey behavior and resource abundance.
This study tested whether habitat configuration (continuous versus patchy) modifies the strength of BMIEs. We manipulated oyster reef habitat in experimental mesocosms with a tri-trophic level food web consisting of either adult blue crab Callinectes sapidus or oyster toadfish Opsanus tau as predator, juvenile blue crab as prey, and ribbed mussel Geukensia demissa as the resource (Fig. 1a). We also compared the amount of resources consumed at edges versus interiors to test for spatial changes in foraging preference within habitat configurations. This particular system is ecologically widespread along the Atlantic and Gulf coasts of the USA and is experimentally tractable. As ecosystem engineers, oysters represent a limited number of species that provide emergent biogenic habitat in the coastal zone. Oyster reef habitats support food webs that can be regulated by BMIEs (e.g. Grabowski 2004, Grabowski et al. 2008, Kimbro et al. 2009), although they are becoming increasingly damaged and fragmented (Rothschild et al. 1994, Macreadie et al. 2011). Damage to oyster reefs via harvesting, boat groundings, anchors, and propellers is common in North Carolina (and elsewhere); however, these sorts of anthropogenic impacts have not been documented for oyster reefs as they have for coral reefs and seagrass beds. This is probably because coral reefs and seagrass beds have long been recognized as critical habitats, whereas the habitat functions of oyster reefs have been ignored until just

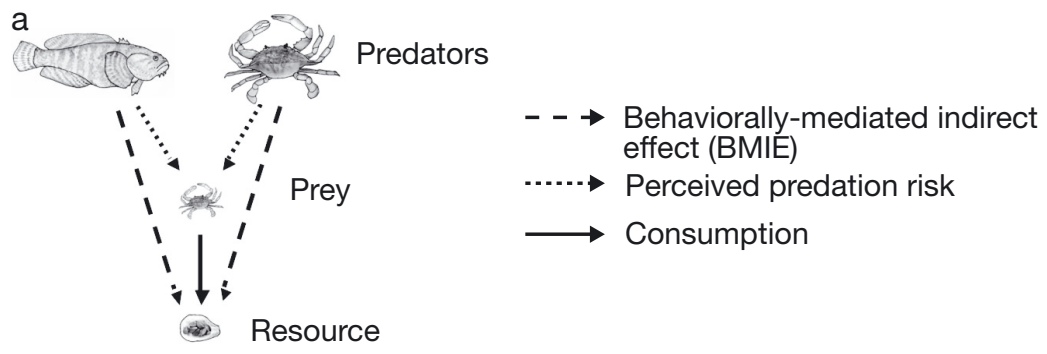

b

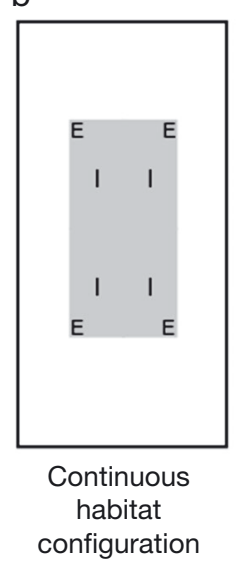

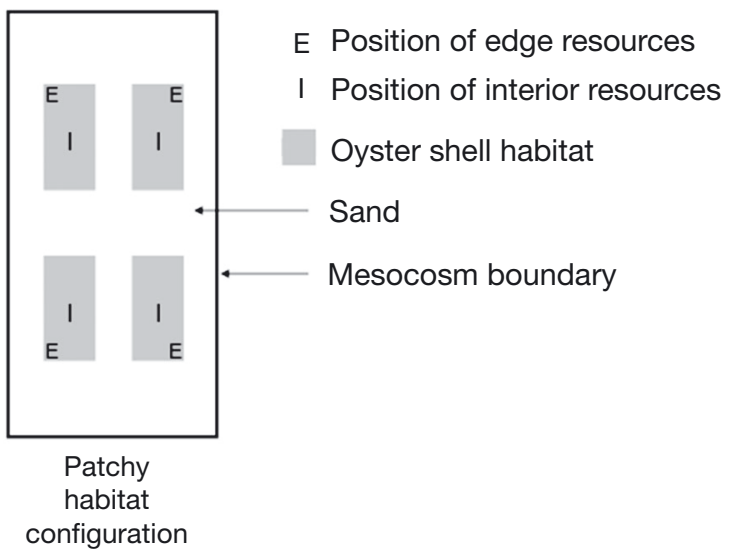

Fig. 1. (a) Schematic diagram showing the organisms (drawn to proportion) used in the experimental oyster reef food web. The 3 trophic levels consisted of non-feeding predators (2 types: oyster toadfish and adult blue crab), prey (juvenile blue crab), and food resource (ribbed mussels). Four different predator combinations were compared, each containing prey and resources, but differing in their predator combinations: adult blue crab, oyster toadfish, both adult blue crab and oyster toadfish, and no predators. Arrows show behaviorally-mediated indirect effects (BMIEs), perceived predation risk, and consumption. The use of different predators allowed a test of whether hunting mode (active pursuit predator versus ambush) affected BMIEs in patchy and continuous environments. (b) Experimental design showing the arrangement of oyster shell habitat on bare sand to give continuous (a single $1 \times 0.5 \mathrm{~m}$ patch) and patchy (4 discrete $0.5 \times 0.25 \mathrm{~m}$ patches) habitat configurations. Resources (ribbed mussels) were positioned at edges (corners) or interiors

( $0.25 \mathrm{~m}$ from the corners) of each patch 
the past decade or two. It is likely that such anthropogenic impacts are a catalyst for the original breaking apart of continuous oyster reefs in North Carolina, and that the patches continue to shrink due to both natural (e.g. limited recruitment capacity, erosion) and human-related causes (e.g. pollution and fishing), leading to fine-scale patchiness (Fig. 2).

Theoretical and empirical models show that the distribution of basal resources (food and habitat) can play a critical role in determining how higher-order animals distribute themselves across habitat edges (Ries \& Sisk 2004, Macreadie et al. 2010c). In seagrass ecosystems, the influence of habitat patchiness on bivalve (resource) abundance is modified by interactions between prey and predator behavior, with juvenile blue crabs (prey) removing more resources from small patches than from large patches when their predators are absent (Hovel \& Regan 2008). Habitat patchiness can also alter predator-prey interactions in ways that may affect the spatial patterns of within-patch exploitation of resources (i.e. edges versus interiors of patches). Abundances of juvenile blue crabs, which are consumed by larger blue crabs (Moksnes et al. 1997, Bishop \& Wear 2005), increase with distance from patch edges
(Bologna \& Heck 1999, Hovel \& Lipcius 2002). This suggests that predators drive prey into patch interiors, potentially leading to higher resource consumption by prey at patch interiors. We predicted that BMIE strength (as seen through differences in resources consumed among and within patches) would vary with habitat configuration and predation risk. By using predators with different hunting modes (blue crabs as actively hunting predators and toadfish as ambush predators), we were also able to assess how both predator hunting mode (Turner et al. 1999, Schmitz 2007, 2009) and habitat fragmentation alter BMIEs.

\section{MATERIALS AND METHODS}

Experiments were conducted at the University of North Carolina's Institute of Marine Sciences (Morehead City, North Carolina, USA) in June 2009. Experiments were established in 12 outdoor stainless steel tanks $(2 \mathrm{~m}$ long $\times 1 \mathrm{~m}$ wide $\times 0.6 \mathrm{~m}$ deep, with a $10 \mathrm{~cm}$ layer of sieved sand on the bottom), supplied with unfiltered seawater (flow rate of $\sim 0.2 \mathrm{l} \mathrm{s}^{-1}$ ) from nearby Bogue Sound. Seawater entered tanks from a

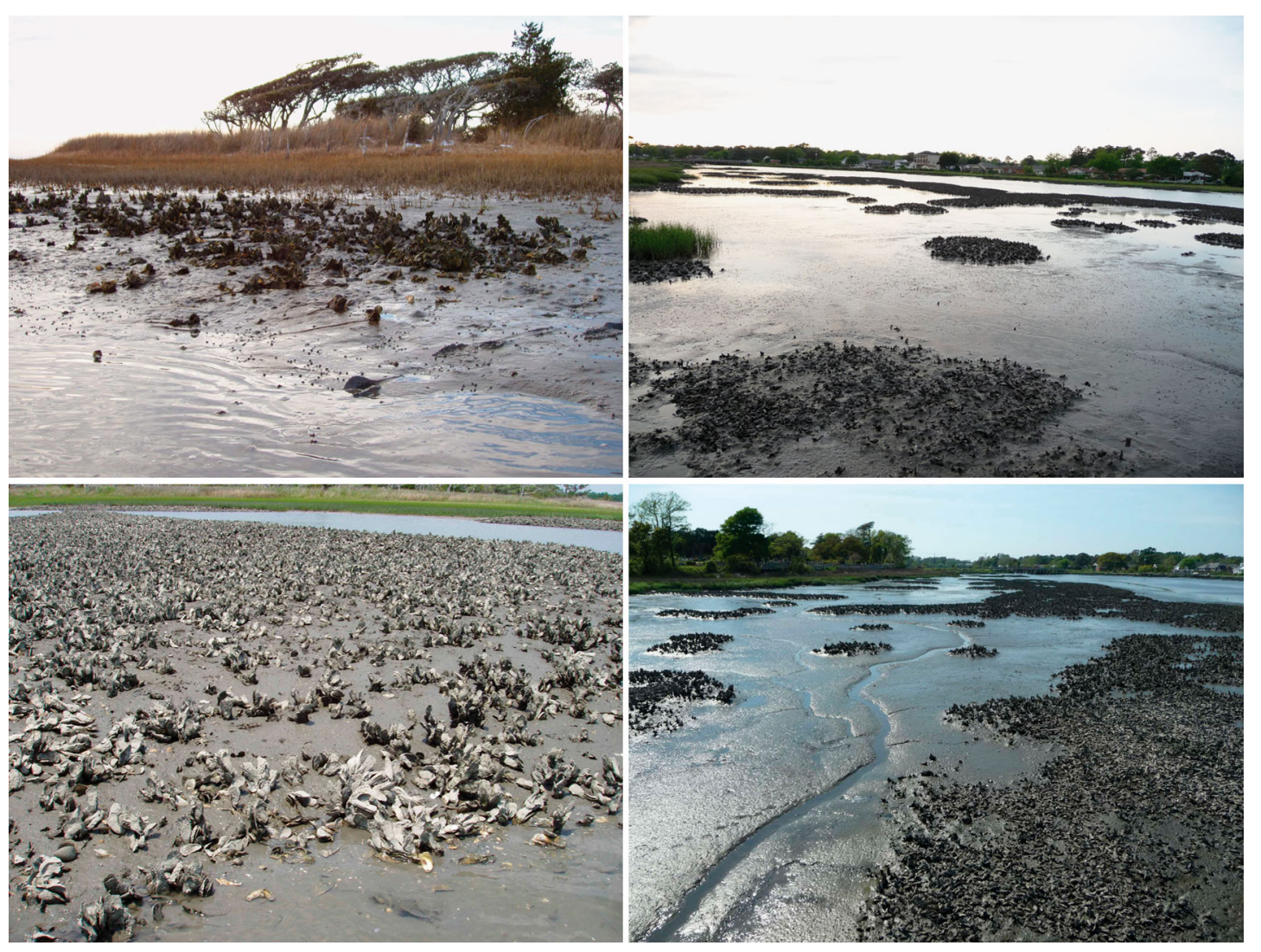

Fig. 2. Oyster reef habitat in North Carolina (USA) showing varying levels of habitat patchiness 
pipe at the water surface and drained out of a standpipe at the other end of the tank. Tanks were covered with a $6 \mathrm{~mm}$ plastic mesh to exclude birds and other terrestrial predators.

In each tank, we manipulated unaggregated shells of adult oysters (3.8 1 of shell per tank) to create 2 habitat configurations: continuous $-\mathrm{a}$ single $1 \times$ $0.5 \mathrm{~m}\left(0.5 \mathrm{~m}^{2}\right)$ oyster shell patch; and patchy - four $0.5 \times 0.25 \mathrm{~m}\left(0.125 \mathrm{~m}^{2}\right)$ oyster shell patches (Fig. 1b). The total amount of oyster reef habitat was equal in the 2 treatments; they differed only in their habitat configuration. Patch sizes were based on a survey of 60 haphazardly selected intertidal and shallow oyster reef patches within Back Sound; patches ranged in area from 0.0009 to $1.22 \mathrm{~m}^{2}$, and the mean $( \pm \mathrm{SE})$ patch size was $0.087 \pm 0.024 \mathrm{~m}^{2}$.

Resources were placed at the edges (corners of patches) and interiors ( $0.25 \mathrm{~m}$ into patches from the corners of the shell patch, and $12.5 \mathrm{~cm}$ to the nearest edge) for both continuous and patchy treatments (Fig. 1B). Resources consisted of clusters of ribbed mussels ( 7 individuals per cluster, each 12 to $22 \mathrm{~mm}$ shell length) attached to the inside surface of a single adult oyster shell. Attachment of mussels to oyster shells occurred naturally via byssal threads within $2 \mathrm{~h}$ of the mussels being placed on the shells (mussels were set on oyster shells a minimum of $12 \mathrm{~h}$ before being used in experiments).

The fully orthogonal design had 4 predator treatments: a single female adult blue crab (139.7 \pm $2.5 \mathrm{~mm}$ carapace width $[\mathrm{CW}]$, mean $\pm \mathrm{SE}, \mathrm{n}=12$ ); a single oyster toadfish $(240.9 \pm 0.4 \mathrm{~mm}$ standard length, $\mathrm{n}=12$ ); an adult blue crab and an oyster toadfish (2 predators); or no predator (control). A single juvenile blue crab $(74.4 \pm 2.5 \mathrm{~mm} \mathrm{CW}, \mathrm{n}=24)$ was introduced as the prey for each replicate of the 8 treatments. Animals were used once in each trial and released. The primary response variable was the amount of resource (number of ribbed mussels) consumed by juvenile blue crabs. Behavioral observations were made of juvenile blue crab activity by noting whether they were buried in sand, buried in oyster shell, roaming, or feeding. Behavioral observations, as well as resource consumption, were recorded at 09:00 and 18:00 h over $48 \mathrm{~h}$ (4 sampling occasions per replicate). The duration of each observation period was 5 min per tank.

To test for BMIEs (Fig. 1A), it was necessary to prevent consumption of prey and resources by predators. For adult blue crabs, this was achieved using a technique described by Newman \& Ward (1973), which simply involved binding the chelae (feeding claws) with plastic-coated electrical wire. No behavioral ef- fects of chelae banding were observed; adult blue crabs still displayed aggressive behaviors in the presence of non-banded conspecifics. Toadfish have very low food requirements (Abbe \& Breitburg 1992) and did not consume either blue crabs or mussels during the experiment, so it was unnecessary to implement strategies to prevent them from feeding. Pilot studies (using the same experimental setup as in the main experiment) verified that neither toadfish nor bound adult blue crabs consumed resources: total resource consumption was $0 \%$ across all replicates $(n=6)$.

Habitat configuration and predator treatment combinations were compared using factorial ANOVAs. Significant results $(\mathrm{p}<0.05)$ with more than 2 levels of a factor were compared with Tukey's honestly significant difference tests using least-squares means. Two response variables were analyzed: (1) the total amount of resource consumed (\%) and (2) the difference in the amount of resource consumed (expressed as a percentage of mussels offered) between patch edges and interiors. The first response variable was taken from the final sampling occasion after $48 \mathrm{~h}$, whereas the second response variable was from the sampling occasion in which just under $50 \%$ of resources was consumed. This was done to avoid depletion effects, which can confound estimation of foraging preference (Murdoch 1969, Peterson \& Renaud 1989). Box plots and normal probability plots were used to test the assumptions of ANOVA (Quinn \& Keough 2002). Because of the limited numbers of tank mesocosms, temporally repeated trials of the experiment were necessary for replication. Each trial (6 in total) consisted of a single replicate of each treatment, randomly assigned to a mesocosm and using a new set of animals on each occasion.

\section{RESULTS}

There was no significant main effect of oyster reef habitat configuration (Fig. 3a), predator treatment (Fig. 3b), or interaction between the two on the total number of mussels consumed by juvenile blue crabs (pooling resource consumptions from edge and interior positions) (Table 1). The presence of predators appeared to induce a decline in total consumption of mussels across both patch configurations, but the pattern was not statistically significant (Fig. 3b). Nevertheless, the difference in resource consumption between edge and interior positions varied significantly with both habitat configuration (Fig. 4a) and predator treatment (Fig. 4b), without significant interaction (Table 1). 
Table 1. Factorial ANOVA comparing the effects of oyster reef habitat configuration (continuous versus patchy) and predator treatment (no predator versus large blue crab versus oyster toadfish versus both large blue crab and toadfish) on resource (ribbed mussel) consumption by a juvenile blue crab. Response variables were total resource consumption and difference in resource consumption between edges and interiors of oyster reef habitat. Significant $\mathrm{p}$-values $(\mathrm{p}<0.05)$ are shown in bold

\begin{tabular}{|lrccc|}
\hline Response variable and factor & df & MS & $F$ & $p$ \\
\hline Total resource consumption & & & & \\
Habitat configuration (H) & 1 & 704.79 & 0.95 & 0.337 \\
Predator treatment (P) & 3 & 1016.22 & 1.36 & 0.268 \\
H $\times$ P & 3 & 136.83 & 0.18 & 0.907 \\
Error & 40 & 745.26 & & \\
& \multicolumn{5}{c}{} \\
Difference in resource consumption between edges and interiors & \\
Habitat configuration (H) & 1 & 14.36 & 4.11 & $\mathbf{0 . 0 4 9}$ \\
Predator treatment (P) & 3 & 16.68 & 4.77 & $\mathbf{0 . 0 0 6}$ \\
H $\times$ P & 3 & 4.22 & 1.21 & 0.319 \\
Error & 40 & 3.50 & & \\
\hline
\end{tabular}

than interior mussels for all 4 predator treatments, and the magnitude of this resource consumption difference between positions was significantly greater in the treatment without a predator than in the toadfish or the toadfish plus adult blue crab treatments by factors of more than 10 (Fig. 4b). The difference between edge and interior mussel consumption for the adult blue crab treatment did not deviate significantly from any other treatment, even though the difference for the no-predator treatment was 2.5 times greater than that of the adult blue crab treatment (Fig. 4 b).

Systematic observations of juvenile blue crabs (prey) illustrate a behavioral switch between habitat configu-
Consumption of mussels by juvenile blue crabs was on average greater at patch edges than interiors for both habitat configuration treatments, whereas the magnitude of this difference was significantly greater in continuous habitat by a factor of 4 (Fig. 4a). Consumption was also higher on average for edge

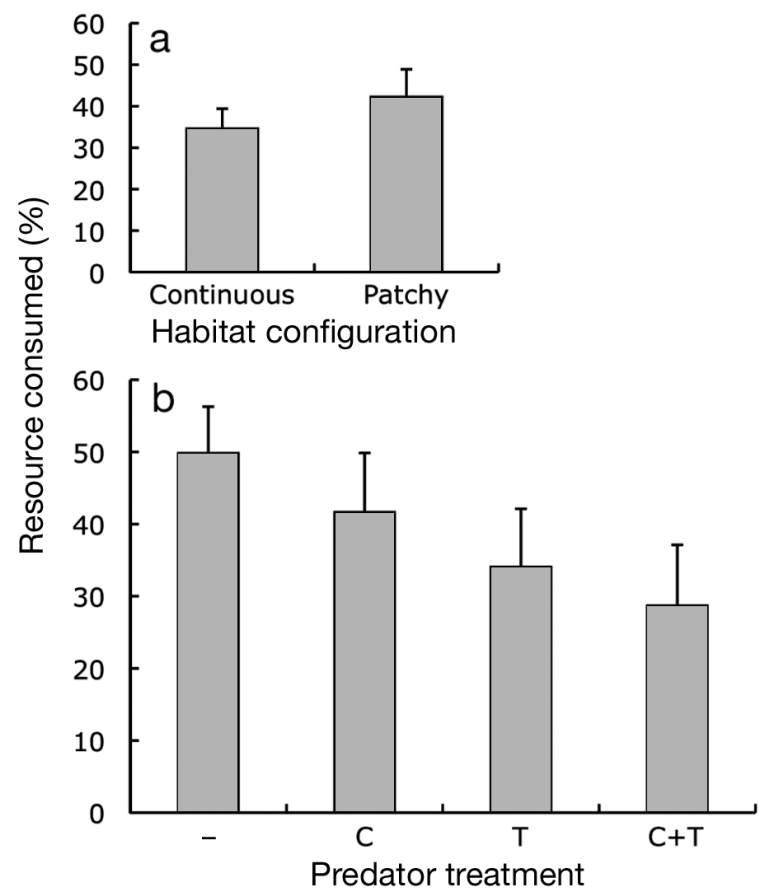

Fig. 3. Percentage of resources consumed by a single juvenile blue crab (prey) in different (a) habitat configurations and (b) predator treatments. Four predator treatments were compared: no predator (-), adult blue crab (C), oyster toadfish $(\mathrm{T})$, and both adult blue crab and oyster toadfish $(\mathrm{C}+\mathrm{T})$. Error bars represent standard error of the mean $(n=6)$

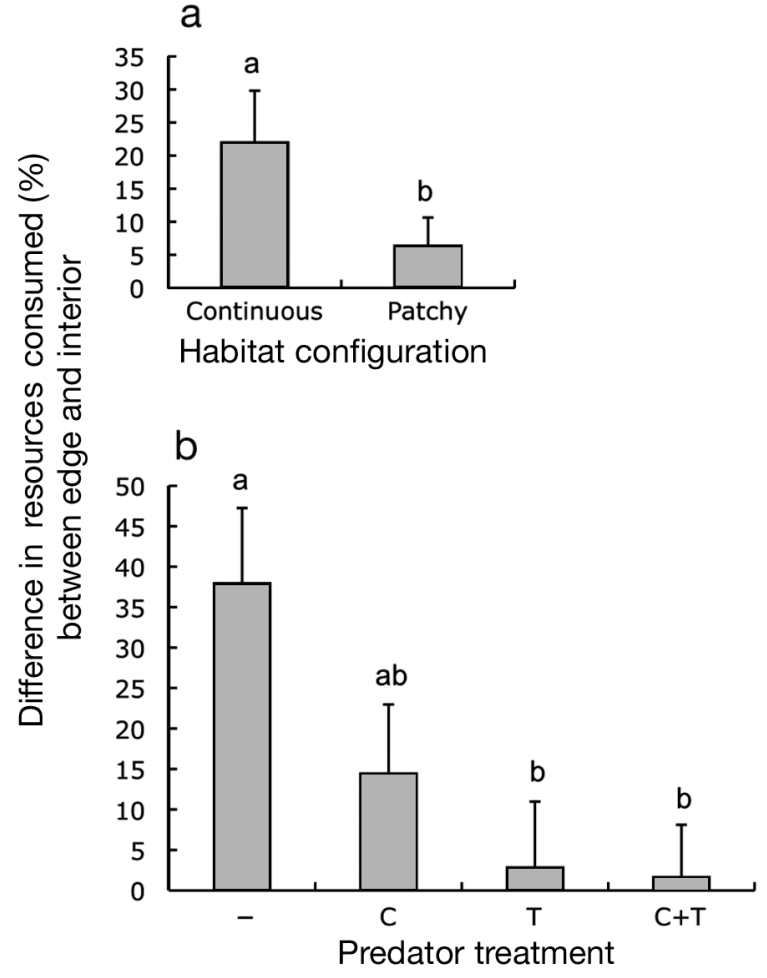

Fig. 4. Difference (interiors minus edges) in the amount of resources consumed (expressed as \%) by a single juvenile blue crab (prey) between edge and interior positions in different (a) habitat configurations and (b) predator treatments. Four predator treatments were compared: no predator $(-)$, adult blue crab $(\mathrm{C})$, oyster toadfish $(\mathrm{T})$, and both adult blue crab and oyster toadfish $(\mathrm{C}+\mathrm{T})$. Significant differences were detected between habitat configurations and among predator treatments (Table 1); shared letters above bars indicate no significant difference at $\mathrm{p}<0.05$ in post hoc Tukey's HSD tests. Error bars represent standard error of the mean 


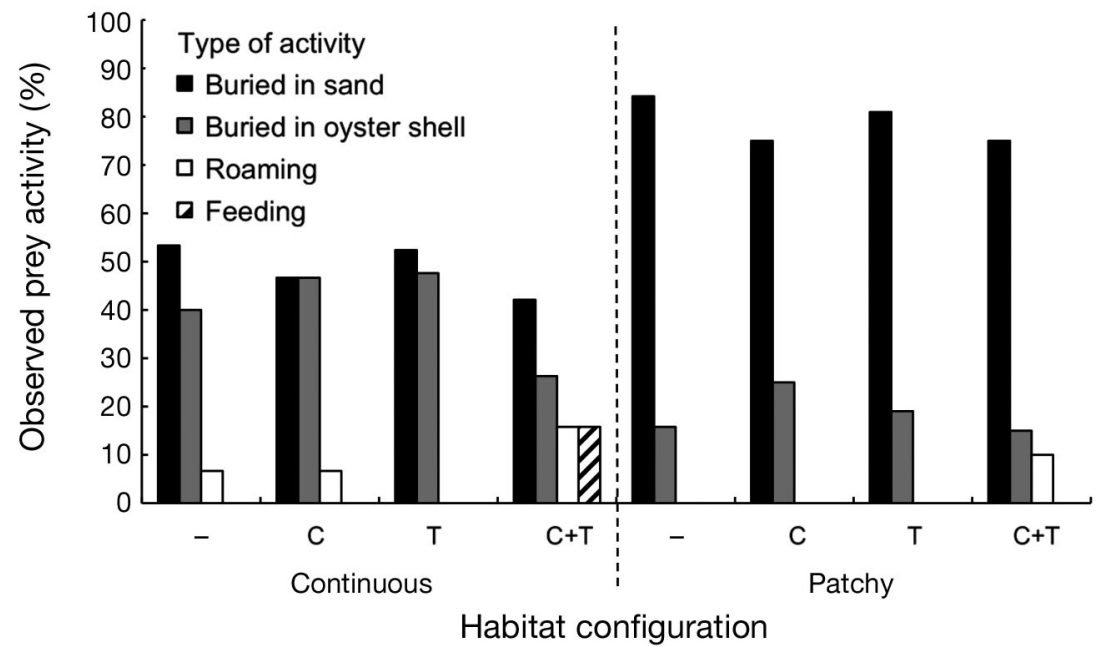

Fig. 5. Observations of juvenile blue crabs (buried in sand, buried in oyster shell, roaming, or feeding) during routine monitoring (09:00 and 18:00 h over 48 h). Data are pooled across monitoring times and replicates, representing the percentage of total observations

ration treatments: in continuous patches, juvenile blue crabs spent similar amounts of time buried in sand and buried in oyster shell, whereas in the small patches they exhibited a preference for burrowing in sand (Fig. 5) even though the total area of oyster shell habitat was identical in both habitat configuration treatments. Only one attempted predatory event was recorded, whereby an adult blue crab chased a feeding juvenile blue crab across a continuous oyster patch.

\section{DISCUSSION}

Using a model aquatic food chain (predator-preyresource), we showed that habitat patchiness and the perceived risk of predation have no effect on total resource consumption from habitat patches, but that these 2 factors can significantly influence the withinpatch pattern of predation on, and thus distribution of, resources. Specifically, we found that habitat patchiness and the presence of predators (non-feeding adult blue crab and oyster toadfish) significantly reduced prey (juvenile blue crab) preference for consuming resources (mussels) at habitat edges relative to habitat interiors. In the absence of predators, the average preference of prey for consuming resources at habitat edges compared with interiors was 4 times stronger in continuous oyster reef habitat than in small habitat patches. However, in the presence of predators, prey did not display a strong preference for resources along edges in continuous oyster reef habitat. These results suggest that habitat patchiness and predator presence can enhance prey exploitation of resources from patch interiors that might otherwise gain refuge from predation in continuous habitats.
Patterns of resource consumption by prey can be explained by trade-offs between perceived predation risk and expected foraging gains. In continuous oyster reef configurations, prey preferred to forage at shell edges, as opposed to interior positions, probably because it is easier for them to move along the sand than on oyster shell (Geraldi et al. 2009) to find resources quickly yet remain near structure, where abundances of food resources are relatively high. When predators were present in the continuous oyster reef configuration, strong predator cues presumably forced prey away from predators (which resided on open sand or along the sand/shell margin) and into the interiors of shell patches, thereby leading to less consumption of resources from shell edges. Heithaus et al. (2009) reported a similar pattern in seagrass systems: pied cormorants Phalacrocorax varius used edges and interiors of seagrass patches in proportion to the abundance of their food resources when their predator (the tiger shark Galeocerdo cuvier) was absent, but shifted to interiors when predation risk increased. The same study also reported escape responses from other prey species (dugongs and turtles); however, a perfect analogy to these species is not applicable here since their escape responses involved moving into deeper waters, whereas our study and the pied cormorant example took place in shallow water, where horizontal moment was the only escape option employed by both prey species.

Adding predation risk in patchy oyster reef configurations did not result in significant changes in resource exploitation between edges and interiors. The prey may not perceive the small patches used in the patchy configuration as a sufficient refuge, causing them to spend more time buried in sand as opposed to seeking shelter from predators at patch 
interiors. Indeed, our behavioral observations indicate that juvenile blue crabs spent equal time in sand and shell in the continuous configuration, but more time in sand when in the patchy configuration. Field studies have also shown that small seagrass patches have lower densities of blue crabs than larger patches (Hovel \& Lipcius 2001), a pattern attributed to increased predation (by fish and birds) in small patches (Hovel \& Regan 2008).

Foraging theory predicts that responses to predation threat will be proportional to the numbers and kinds of predator cues present (Vadas et al. 1994). The presence of predators greatly reduced juvenile blue crab preference for consuming mussels at habitat edges compared with interior locations, but this BMIE was significant only for the ambush predator (toadfish) and the treatment containing both predators, and not for the actively hunting predator (adult blue crab). The difference between predator species was not significant, which could indicate that more statistical power is needed to detect a significant BMIE for the adult blue crab. It is also possible that the ambush predator is responsible for the significant effect in the treatment containing both predators. Differences in the BMIE depending on hunting mode are consistent with conclusions of Schmitz (2008), who found that cues from ambush predators evoked stronger BMIEs than cues from actively hunting predators. Schmitz (2008) suggested that behavioral responses of prey to ambush predators are stronger because ambush predators spend more time remaining inactive, meaning that they create persistent point-source cues. By contrast, widely roaming, actively hunting predators produce highly variable predation cues and are thus less likely to cause chronic behavioral responses in their prey.

Management strategies in coastal systems increasingly recognize the importance of spatial context (especially degrees of habitat fragmentation and resulting patchiness) in population models that predict the persistence of populations (including the blue crab, which supports a valuable fishery; Mizerek et al. 2011). The capacity of such models will be greatly enhanced through incorporation of BMIEs. For example, there is a negative relationship between abundance of foraging blue crabs and prey densities of bivalves, including ribbed mussels (Seed 1980, 1982); however, information on the complex dynamics of benefits and disadvantages of edges and interior zones of patchy habitats has been lacking (Hines 2007), and our study now helps fill this gap. We also add a level of complexity (namely, within-habitat variability) to the existing individual-based blue crab model developed by Hovel \& Regan (2008), which examines the roles of habitat fragmentation and behavior on predator-prey relationships using juvenile blue crabs as prey and adult blue crabs as predators.

There are several caveats of this study that deserve mention. First, as with any mesocosm study, it is possible that the mesocosm boundaries (which are necessary for containing organisms and isolating mechanisms) influenced the predator-prey dynamics (Englund 1997) in some fashion, thereby altering resource exploitation. Second, we distributed resources in equal quantities at patch edges and interiors, whereas under natural settings, resources can vary in density between habitat edges and interiors (Ries et al. 2004, Macreadie et al. 2010a). Third, the patch sizes used in this study are at the lower (although common) end of the naturally occurring range in North Carolina. Because patch size can influence the direction and strength of edge effects (Didham et al. 1998, Ewers et al. 2007, Macreadie et al. 2009, Smith et al. 2010), further work is needed to determine whether larger patch sizes induce similar changes in resource abundance. Based on our data, we predict that increasingly larger habitat patch sizes will improve the persistence of basal resources at patch interiors when apex predators are absent.

In summary, this study provides a rare demonstration of how both habitat patchiness and BMIEs jointly affect within-habitat consumption of resources and thereby their distribution. Using a predator-preyresource food chain, we found that both predator presence and habitat patchiness diminished the general preference of prey for foraging at habitat edges. Our findings imply that increasing levels of habitat patchiness and predator presence can have cascading effects through food webs that lead to enhanced exploitation of interior resources that would otherwise have lower predation. With increasing levels of habitat fragmentation around the globe, these results are valuable for understanding the relative importance of BMIEs and mechanisms that maintain edge effects in resource distributions. We conclude that predator presence and habitat patchiness can jointly affect within-patch resource distribution by causing spatial shifts in prey foraging, thereby highlighting the need to incorporate an understanding of riskbased behaviors into studies on habitat patchiness and fragmentation.

Acknowledgements. We thank L. Brown, T. Creech, J. Meiners, J. Moore, and W. Rogers for field and laboratory assistance. Comments by M. Bishop, S. Fegley, B. VanDusen, and anonymous referees improved this manuscript. Funding was 
provided by the National Oceanic and Atmospheric Administration (NOAA) Ecological Effects of Sea Level Rise Program (C.H.P.), the North Carolina Coastal Recreational Fishing License Program (C.H.P., N.R.G.), the Cooperative Institute for Coastal and Estuarine Environmental Technology (C.H.P.), a Dow Chemical Company Fellowship (P.I.M.), a Brian Robinson Fellowship (P.I.M.), and a NOAA National Estuarine Research Reserve Fellowship (N.R.G.).

\section{LITERATURE CITED}

Abbe GR, Breitburg DL (1992) The influence of oyster toadfish (Opsanus tau) and crabs (Callinectes sapidus and Xanthidae) on the survival of oyster (Crassostrea virginica) spat in Chesapeake Bay: does spat protection always work? Aquaculture 107:21-31

> Abrams PA (2008) Measuring the impact of dynamic antipredator traits on predator-prey-resource interactions. Ecology 89:1640-1649

Bishop MJ, Wear SL (2005) Ecological consequences of ontogenetic shifts in predator diet: seasonal constraint of a behaviorally mediated indirect interaction. J Exp Mar Biol Ecol 326:199-206

> Bologna PAX, Heck KL (1999) Differential predation and growth rates of bay scallops within a seagrass habitat. J Exp Mar Biol Ecol 239:299-314

> Carpenter SR, Kitchell JF, Hodgson JR, Cochran PA and others (1987) Regulation of lake primary productivity by food web structure. Ecology 68:1863-1876

- Crooks KR, Soule ME (1999) Mesopredator release and avifaunal extinctions in a fragmented system. Nature 400: 563-566

> Didham RK, Hammond PM, Lawton JH, Eggleton P, Stork NE (1998) Beetle species responses to tropical forest fragmentation. Ecol Monogr 68:295-323

Englund G (1997) Importance of spatial scale and prey movements in predator caging experiments. Ecology 78: 2316-2325

Estes JA, Duggins DO (1995) Sea otters and kelp forests in Alaska: generality and variation in a community ecological paradigm. Ecol Monogr 65:75-100

$>$ Ewers RM, Didham RK (2006) Confounding factors in the detection of species responses to habitat fragmentation. Biol Rev Camb Philos Soc 81:117-142

> Ewers RM, Thorpe S, Didham RK (2007) Synergistic interactions between edge and area effects in a heavily fragmented landscape. Ecology 88:96-106

- Garrity SD, Levings SC (1981) A predator-prey interaction between two physically and biologically constrained tropical rocky shore gastropods: direct, indirect and community effects. Ecol Monogr 51:267-286

> Geraldi NR, Powers SP, Heck KL, Cebrian J (2009) Can habitat restoration be redundant? Response of mobile fishes and crustaceans to oyster reef restoration in marsh tidal creeks. Mar Ecol Prog Ser 389:171-180

Grabowski JH (2004) Habitat complexity disrupts predator-prey interactions but not the trophic cascade on oyster reefs. Ecology 85:995-1004

Grabowski JH, Hughes AR, Kimbro DL (2008) Habitat complexity influences cascading effects of multiple predators. Ecology 89:3413-3422

Hall DJ, Cooper WE, Werner EE (1970) Experimental approach to production dynamics and structure of freshwater animal communities. Limnol Oceanogr 15:839-928
Heithaus MR, Frid A, Wirsing AJ, Dill LM, Fourqurean JW, Burkholder D, Thomson J, Bejder L (2007) State-dependent risk-taking by green sea turtles mediates top-down effects of tiger shark intimidation in a marine ecosystem. J Anim Ecol 76:837-844

Heithaus MR, Frid A, Wirsing AJ, Worm B (2008) Predicting ecological consequences of marine top predator declines. Trends Ecol Evol 23:202-210

> Heithaus MR, Wirsing AJ, Burkholder D, Thomson J, Dill LM (2009) Towards a predictive framework for predator risk effects: the interaction of landscape features and prey escape tactics. J Anim Ecol 78:556-562

Hines AH (2007) Ecology of juvenile and adult blue crabs. In: Kennedy VS, Cronin LE (eds) The blue crab Callinectes sapidus. Maryland Sea Grant College, College Park, MD, p 565-654

> Hovel KA, Lipcius RN (2001) Habitat fragmentation in a seagrass landscape: patch size and complexity control blue crab survival. Ecology 82:1814-1829

> Hovel KA, Lipcius RN (2002) Effects of seagrass habitat fragmentation on juvenile blue crab survival and abundance. J Exp Mar Biol Ecol 271:75-98

> Hovel KA, Regan HM (2008) Using an individual-based model to examine the roles of habitat fragmentation and behavior on predator-prey relationships in seagrass landscapes. Landscape Ecol 23:75-89

$>$ Huang CF, Sih A (1991) Experimental studies on direct and indirect interaction in a three trophic-level stream system. Oecologia 85:530-536

- Kareiva P (1987) Habitat fragmentation and the stability of predator-prey interactions. Nature 326:388-390

> Kimbro DL, Grosholz ED, Baukus AJ, Nesbitt NJ, Travis NM, Attoe S, Coleman-Hulbert C (2009) Invasive species cause large-scale loss of native California oyster habitat by disrupting trophic cascades. Oecologia 160:563-575

- Macreadie PI, Hindell JS, Jenkins GP, Connolly RM, Keough MJ (2009) Fish responses to experimental fragmentation of seagrass habitat. Conserv Biol 23:644-652

Macreadie PI, Connolly RM, Jenkins GP, Hindell JS, Keough MJ (2010a) Edge patterns in aquatic invertebrates explained by predictive models. Mar Freshw Res 61:214-218

> Macreadie PI, Connolly RM, Keough MJ, Jenkins GP, Hindell JS (2010b) Short-term differences in animal assemblages in patches formed by loss and growth of habitat. Austral Ecol 35:515-521

Macreadie PI, Hindell JS, Keough MJ, Jenkins GP, Connolly RM (2010c) Resource distribution influences positive edge effects in a seagrass fish. Ecology 91:2013-2021

> Macreadie PI, Geraldi NR, Peterson CH (2011) How smallscale variation in oyster reef patchiness influences predation on bivalves. Mar Ecol Prog Ser 429:87-91

> Mizerek T, Regan HM, Hovel KA (2011) Seagrass habitat loss and fragmentation influence management strategies for a blue crab Callinectes sapidus fishery. Mar Ecol Prog Ser 427:247-257

Moksnes PO, Lipcius RN, Pihl L, vanMontfrans J (1997) Cannibal-prey dynamics in young juveniles and postlarvae of the blue crab. J Exp Mar Biol Ecol 215:157-187

> Morris DW, Davidson DL (2000) Optimally foraging mice match patch use with habitat differences in fitness. Ecology 81:2061-2066

Murdoch WW (1969) Switching in general predators: experiments on predator specificity and stability of prey populations. Ecol Monogr 39:335-354 
Myers RA, Baum JK, Shepherd TD, Powers SP, Peterson CH (2007) Cascading effects of the loss of apex predatory sharks from a coastal ocean. Science 315:1846-1850

Newman MW, Ward GE (1973) A technique for the immobilization of the chelae of blue crabs and identification of individual animals. Chesap Sci 14:68-69

> Orrock JL, Danielson BJ (2005) Patch shape, connectivity, and foraging by oldfield mice (Peromyscus polionotus). J Mammal 86:569-575

$>$ Peterson CH, Renaud PE (1989) Analysis of feeding preference experiments. Oecologia 80:82-86

Preisser EL, Bolnick DI, Benard MF (2005) Scared to death? The effects of intimidation and consumption in predator-prey interactions. Ecology 86:501-509

Quinn GP, Keough MJ (2002) Experimental design and data analysis for biologists. Cambridge University Press, Cambridge

Ries L, Sisk TD (2004) A predictive model of edge effects. Ecology 85:2917-2926

> Ries L, Fletcher RJ, Battin J, Sisk TD (2004) Ecological responses to habitat edges: mechanisms, models, and variability explained. Annu Rev Ecol Evol Syst 35:491-522

Rothschild BJ, Ault JS, Goulletquer P, Heral M (1994) Decline of the Chesapeake Bay oyster population: a century of habitat destruction and overfishing. Mar Ecol Prog Ser 111:29-39

Schmitz OJ (2007) Predator diversity and trophic interactions. Ecology 88:2415-2426

Schmitz OJ (2008) Effects of predator hunting mode on grassland ecosystem function. Science 319:952-954

Schmitz OJ (2009) Effects of predator functional diversity on

Editorial responsibility: Tim McClanahan,

Mombasa, Kenya grassland ecosystem function. Ecology 90:2339-2345

Schmitz OJ, Beckerman AP, Obrien KM (1997) Behaviorally mediated trophic cascades: effects of predation risk on food web interactions. Ecology 78:1388-1399

Seed R (1980) Predator-prey relationships between the mud crab Panopeus herbstii, the blue crab, Callinectes sapidus and the atlantic ribbed mussel Geukensia (= Modiolus) demissa. Estuar Coast Mar Sci 11:445-458

$>$ Seed R (1982) Predation of the ribbed mussel Geukensia demissa by the blue crab Callinectes sapidus. Neth J Sea Res 16:163-172

Smith TM, Hindell JS, Jenkins GP, Connolly RM (2010) Seagrass patch size affects fish responses to edges. J Anim Ecol 79:275-281

Trussell GC, Ewanchuk PJ, Matassa CM (2006) Habitat effects on the relative importance of trait- and densitymediated indirect interactions. Ecol Lett 9:1245-1252

Turner AM, Fetterolf SA, Bernot RJ (1999) Predator identity and consumer behavior: differential effects of fish and crayfish on the habitat use of a freshwater snail. Oecologia 118:242-247

- Vadas RL, Burrows MT, Hughes RN (1994) Foraging strategies of dogwhelks, Nucella lapillus (L.): interacting effects of age, diet and chemical cues to the threat of predation. Oecologia 100:439-450

Werner EE, Peacor SD (2003) A review of trait-mediated indirect interactions in ecological communities. Ecology 84:1083-1100

Wolf M, Batzli G (2004) Forest edge-high or low quality habitat for white-footed mice (Peromyscus leucopus)? Ecology 85:756-769

Submitted: March 9, 2012; Accepted: August 6, 2012

Proofs received from author(s): October 8, 2012 